НАУКОВИЙ ВІСНИК

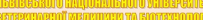

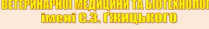

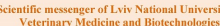
(1)

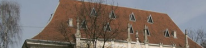
311) MnN

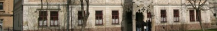

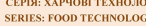
Том 23 № 95 2021
Науковий вісник Львівського національного університету ветеринарної медицини та біотехнологій імені С.3. Гжицького. Серія: Харчові технології

Scientific Messenger of Lviv National University of Veterinary Medicine and Biotechnologies.

Series: Food Technologies

ISSN 2519-268X print

ISSN 2707-5885 online doi: 10.32718/nvlvet-f9504

https://nvlvet.com.ua/index.php/food

UDC 539.23:621.38:541.64

\title{
Detection of the organic solvent vapors by the optical gas sensors based on polyaminoarenes
}

\author{
O. I. Aksimentyeva ${ }^{1}$, B. R. Tsizh ${ }^{2,3}$, Yu. Yu. Horbenko ${ }^{1}$, A. L. Stepura ${ }^{1}$ \\ ${ }^{I}$ Ivan Franko National University of Lviv, Lviv, Ukraine \\ ${ }^{2}$ Kazimierz Wielki University in Bydgoszcz, Bydgoszcz, Poland \\ ${ }^{3}$ Stepan Gzhytskyi National University of Veterinary Medicine and Biotechnologies Lviv, Ukraine
}

Article info

Received 07.01.2021

Received in revised form 10.02 .2021

Accepted 11.02.2021

Ivan Franko National University of Lviv,

Kyryla i Mefodiya Str., 6,

Lviv, 79005, Ukraine.

Kazimierz Wielki University in Bydgoszcz, 30 Chodkiewicza,

Bydgoszcz, 85-064, Poland.

Stepan Gzhytskyi National University of Veterinary Medicine and Biotechnologies Lviv, ekarska Str., 50, Lviv, 79010, Ukraine.

Tel.: +38-032-239-26-35

E-mail:tsizhb@ukr.net
Aksimentyeva, O. I., Tsizh, B. R., Horbenko, Yu. Yu., \& Stepura, A. L. (2021). Detection of the organic solvent vapors by the optical gas sensors based on polyaminoarenes. Scientific Messenger of Lviv National University of Veterinary Medicine and Biotechnologies. Series: Food Technologies, 23(95), 20-24. doi: 10.32718/nvlvet-f9504

The important problem to ensure the safety of life is the development of effective methods for monitoring of toxic gases in the atmosphere and industrial premises. To ensure such control, various gas sensors are developed that work on the effects of changes in electrical resistance, optical absorption or radiation in a certain spectral range. Most known gas sensors have high operating temperatures, which creates some difficulties in their operation, so more and more attention is paid to sensors based on conjugated electrically conductive polymers, in particular, polyaminoarenes. In result of absorption of inorganic polar gases such as ammonia, nitrogen oxide, hydrogen chloride and others the significant changes in conductivity, optical absorption and morphology of polyaminoarene films are observed. However influence of organic solvent vapors on the optical spectra of polyaminoarene films for today is poorly studied. In the present work the functional polymer films of polyanisidine (PoA) and polytoluidine (PoTI) are proposed as sensitive elements of optical sensors operating at room temperatures. The sensitive films on the transparent $\mathrm{SnO}_{2}$ surface were prepared by electrodeposition. The influence of vapors of organic solvents (dimethylformamide, tetrahydrofuran, chloroform, nitrobenzene, toluene) on the optical characteristics of PoTi and PoA films was established. The optical absorption spectra investigated PoA film was characterized by two band with maximum near 360-410 $\mathrm{nm}$ ( $\pi-\pi^{*}$ transition) and broad band in the range of 620-950 $\mathrm{nm}$ which is a superposition of the second and third bands. Influence of organic vapors causes the changes in films coloration. The maximum of sensitivity to the organic vapors for PoTI films in all cases is observed at $\lambda>550 \mathrm{~nm}$ and extends to near-infra-red area indicating a formation of free charge carriers of polaron type. Nonpolar solvent vapors insignificantly affect the optical properties of polyaminoarene films responces to spectral changes in the visible and NIR range of spectrum. A highest gas sensitivity of optical signal was observed under influence of dimethylformamide and tetrahydrofuran vapors. The time to establish the steady-state value of the optical response is 30-60 s for PoTi, while for PoA reaches 120-180 s depending on the nature of organic vapors.

Key words: optical sensor, absorption, organic solvents, polyanisidine, polytoluidine.

\section{Визначення парів органічних розчинників оптичними сенсорами на основі поліаміноаренів}

\author{
О. І. Аксіментьєва ${ }^{1}$, Б. Р. Ціж $ж^{2,3}$, Ю. Ю. Горбенко ${ }^{1}$, А. Л. Степура ${ }^{1}$ \\ ${ }^{1}$ Львівський національний університет імені Івана Франка, м. Львів, Украйна \\ ${ }^{2}$ Університет Казимира Великого в Бидгощі, Бидгощ, Польща \\ ${ }^{3}$ Львівський національний університет ветеринарної медицини та біотехнологій імені С. 3. Гэсииького, м. Львів, \\ Україна
}


Важливою проблемою гарантування безпеки життєдіяльності людей є розробка ефективних методів контролю токсичних газів в атмосфері та виробничих приміщеннях. Для здійснення такого контролю розробляються різноманітні газові сенсори, які працюють на ефектах зміни електричного опору, оптичного поглинання чи випромінювання у певному спектральному діапазоні. Більшість відомих газових сенсорів мають високі робочі температури, щзо ускладнює їхню експлуатацію, тому все більше уваги приділясться датчикам на основі спряжених електропровідних полімерів, зокрема поліаміноаренів. У результаті поглинання неорганічних полярних газів, таких як аміак, оксид азоту, хлороводень та інші, спостерігаються значні зміни провідності, оптичного поглинання та морфології поліаміноаренових плівок. Однак вплив парів органічних розчинників на оптичні спектри поліаміноаренів на сьогодні недостатньо вивчений. В цій роботі функціональні полімерні плівки поліанізидину (РоА) та політолуїдину (РоТІ) пропонуються як чутливі елементи оптичних датчиків, щчо працюють за кімнатних температур. Сенсорні плівки отримували електроосадженням полімерів на поверхню прозорих $\mathrm{SnO}_{2}$ електродів. Встановлено вплив парів органічних розчинників (диметилформамід, тетрагідрофуран, хлороформ, нітробензол, толуол) на оптичні характеристики плівок РоТі та РоА. Спектри оптичного поглинання досліджуваної плівки РоА характеризувались двома смугами з максимумом близько $360-410$ нм (перехід $\pi-\pi$ *) та широкою смугою в діапазоні 620-950 нм, щзо є суперпозицією другої та третьої смуг. Вплив органічних парів спричиняє зміни забарвлення плівок, щуо відповідає спектральним змінам видимого та NIR-діапазону спектру. Найвища газочутливість оптичного сигналу для ПоТі спостерігалась під впливом парів диметилформаміду та тетрагідрофурану. Максимум чутливості до органічних парів для плівок РоТІ у всіх випадках спостерігається при $\lambda>550$ нм і поширюється на майже інфрачервону область, шцо вказує на утворення вільних носїв заряду поляронового типу. Неполярні пари розчинників суттєво впливають на оптичні властивості плівок поліаміноарену у відповідь на спектральні зміни видимого та NIR-діапазону спектру. Час встановлення стаціонарного значення оптичного відгуку становить 30-60 с для ПоТі, тимчасом як для ПоА досягає 120-180 с залежно від природи органічних парів.

Ключові слова: оптичний датчик, абсорбиія, органічні розчинники, поліанізидин, полі толуїдин.

\section{Introduction}

Due to environmental degradation situations in Ukraine and in the world an important problem is the development of effective methods for monitoring of toxic gases in the atmosphere and industrial premises. Special devices (sensors) allow detecting harmful factors below the limit of their perception by human senses organs (Dong et al., 2016; Aksimentieva et al., 2018; Aksimentyeva et al., 2019; Tsizh \& Aksimentyeva, 2020). The key elements of sensors, regardless of their design, are an indicator substance - a sensory medium that changes its properties (optical, electrical, etc.) in response to an external action. Most known gas sensors have high operating temperatures, which creates certain difficulties in their operation, so more and more attention is paid to sensors based on conjugated electrically conductive polymers, in particular, polyaminoarenes operating at room temperatures. The interesting optical phenomena, which are inherent in conjugated polyaminoarenes and are part of their specific properties, are the ability to optical transformations, namely - changes in the spectra of optical absorption under the influence of external factors, including gas adsorption (Bai et al., 2007; Hu et al., 2017; Aksimentieva et al., 2018). Of interest are the optical properties of conjugated polymer systems, which are detected both in the visible range of the spectrum and in the near-IR and UV regions.

Among the sensor materials based on conducting polymers the polyaniline is mostly studied (Dong et al., 2016; Tsizh \& Aksimentyeva, 2020) while its derivatives are under-researched. Our attention is devoted to polytoluidine (PoTI) and polyanisidine (PoA) due its high sensitivity to influence of external chemical and physical factors, especially adsorption of gas molecules (Savale et al., 2007; Horbenko \& Aksimentyeva, 2013; Khan et al., 2015; Tsizh et al., 2017; Aksimentieva et al., 2018). In result of absorption of inorganic polar gases such as ammonia, nitrogen oxide, hydrogen chloride and others the significant changes in conductivity, optical absorption and morphology of polyaminoarene films are observed (Bai et al., 2007; Aksimentieva et al., 2018). This may be used for creation the sensitive elements for both resistive and optical type of sensors. However, the effect of the vapors of organic solvents on the optical spectra of PoTI and PoA films for today is poorly studied. In the present work we investigated influence of the adsorption of organic solvents - chloroform, tetrahydrofuran (THF), dimethylformamide (DMF), toluene and benzene, etc. on the optical spectra of PoTI and PoA thin films on the transparent $\mathrm{SnO}_{2}$ surface.

\section{Material and methods}

The thin films of PoTI and PoA were obtained by the method of "in situ" electrochemical polymerization of $o$ toluidine and $o$-anisidine on the transparent surface of the conductive $\mathrm{SnO}_{2}$ coated glass as described in (Tsizh et al., 2017). Electrosynthesis was realized under cyclic sweeping potential in the range from 0 to $1.0 \mathrm{~V}(\mathrm{Ag} / \mathrm{AgCl})$ at sweep rate of $50 \mathrm{mV} / \mathrm{s}$ and the number of cycles $\mathrm{N}=50$. As a power source used the potentiostat PI-50 paired with a digital controller MTech CON-PI-50-2. Optical absorption spectra of the obtained films were recorded in quartz cells using a SF-46 spectrophotometer (spectral range 200-1100 nm) and a KFK-3 photoelectrocolorimeter. Operating wavelength range - from 400 to $900 \mathrm{~nm}$. All measurements were carried out at room temperature. Thickness of the films measured with microinterferomer MII-4 was $360 \pm 20 \mathrm{~nm}$.

\section{Results and discussion}

The optical absorption spectra of polyaminoarenes typically are characterized by three bands. The first peak at a wavelength of $370-420 \mathrm{~nm}$ corresponds to $\pi-\pi^{*}$ transition in band gap, second peak of absorption at the $620-650 \mathrm{~nm}$ can be attributed to the $n-\pi^{*}$ transition in amino-quinoid fragments of the polymer system and third band at $\lambda>800$ $\mathrm{nm}$ due to the absorption of delocalized charge carriers in polaron - bipolaron zone (Aksimentieva et al., 2018; Hu et al., 2017).

The optical absorption spectra investigated PoA film was characterized by two band with maximum near 360$410 \mathrm{~nm}\left(\pi-\pi^{*}\right.$ transition) and broad band in the range of $620-950 \mathrm{~nm}$ which is a superposition of the second and 
third bands (fig. 1, curve 1). Influence of organic vapors causes the changes in films coloration that corresponds to spectral changes in the visible and NIR range of spectrum. Under action of organic vapors, the strong changes of optical absorption are observed in the spectra of PoTI and PoA films. However, a character of these variations is depended on the nature of polyaminoarenes and organic solvents.
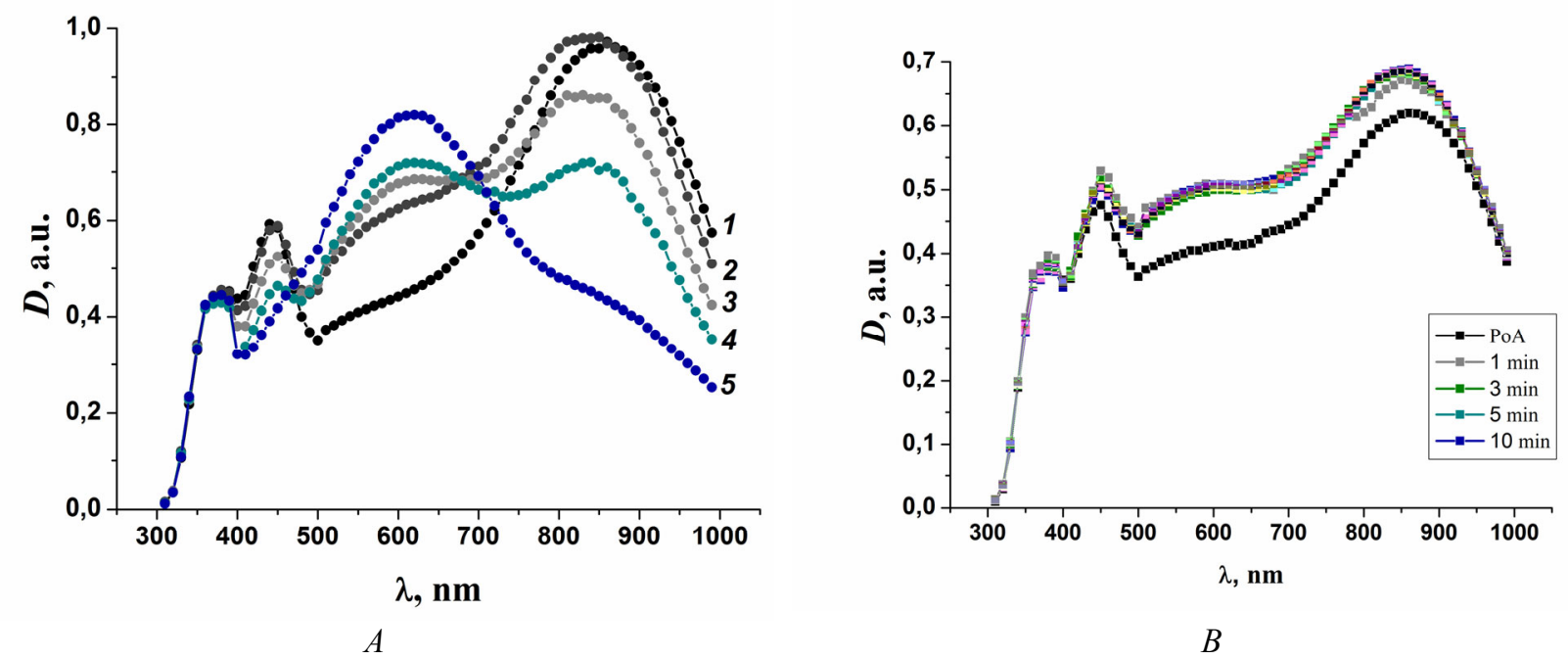

Fig. 1. Optical absorption spectra of PoA film (1), and after exposure to $(a)$ dimethylformamide (DMF) and $(b) \mathrm{THF}$ vapor vapor for: $1 \min (2), 3 \min (3), 5 \min (4)$, and $10 \min (5) ; P=7.2 \mathrm{kPa}$

In optical spectra of PoA films influenced by DMF or THF vapors two or three isosbestic points at 480 and 750 nm are observed (fig. 1). Increasing of contact time of DMF vapors with PoA film has a specific character in different spectral interval: a growth of absorption in the ranges of $400-450 \mathrm{~nm}$ and $550-650 \mathrm{~nm}$ (fig.1) and decrease of optical density in the near-infra-red range of $\lambda=800-1000 \mathrm{~nm}$.
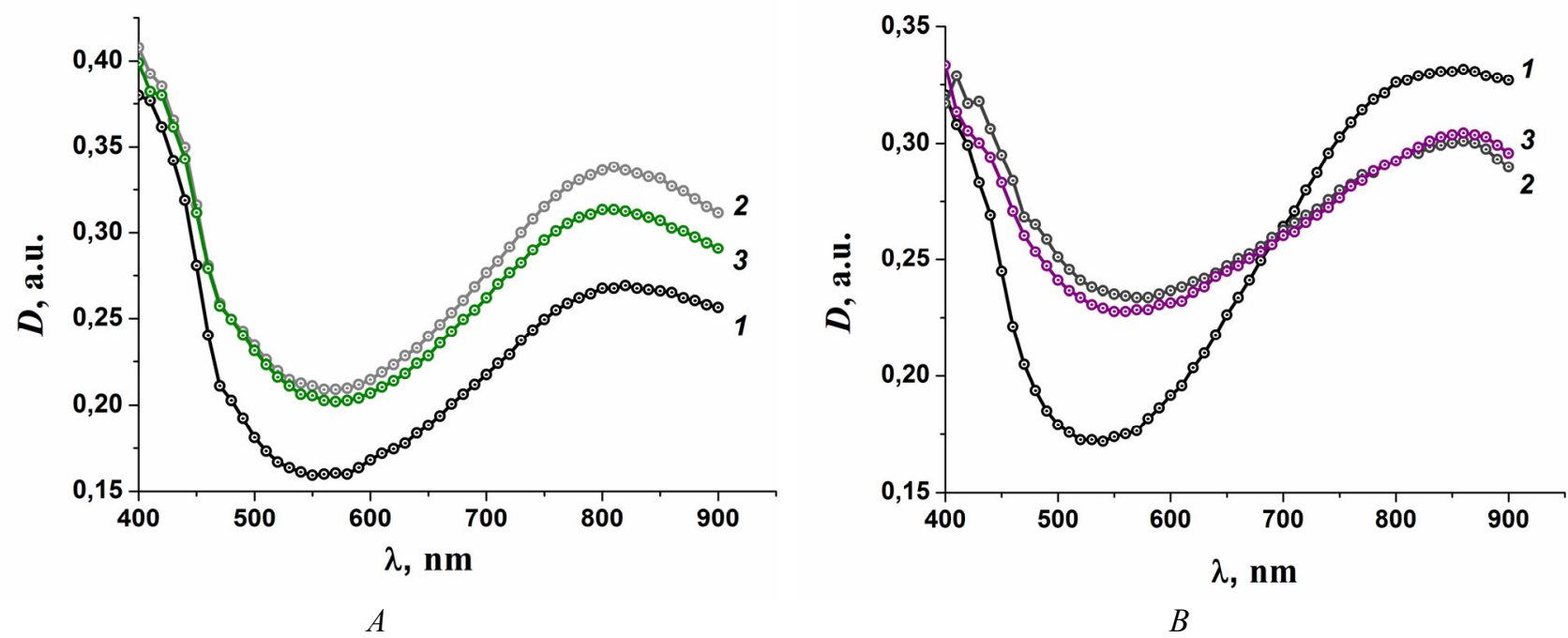

Fig. 2. Spectral absorption curves of the initial PoTi films (1) in (a) chloroform and (b) DMF vapors at a holding time of $30(2)$ and $60(3) \mathrm{s}$

As can be seen from fig. 1 and 2, the dynamics of changes in optical absorption under the action of organic solvent vapors consists in a decrease of absorption in the NIR range and an increase in absorption in the $n-\pi^{*}$ transition in amino-quinoid fragments. Adsorption of polar organic solvents on the PoA or PoTI surface decreases an electron delocalization in conjugated polymer chain and may change a microstructure and morphology of the polymer films in accord with a picture of inhomogeneous order in these materials (Aksimentieva et al., 2018; Hu et al., 2017) as one can see from fig. 3, $a, b$. 


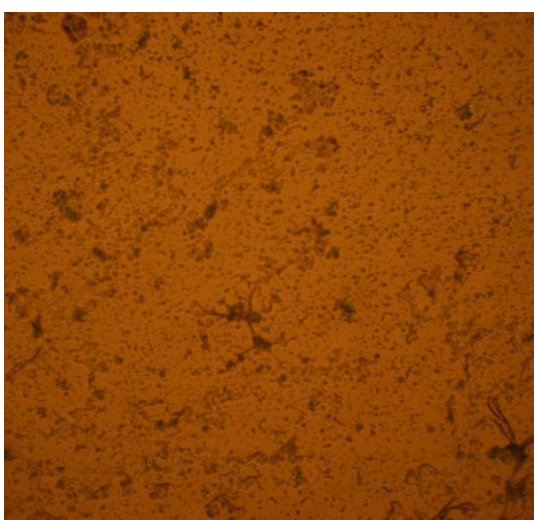

A

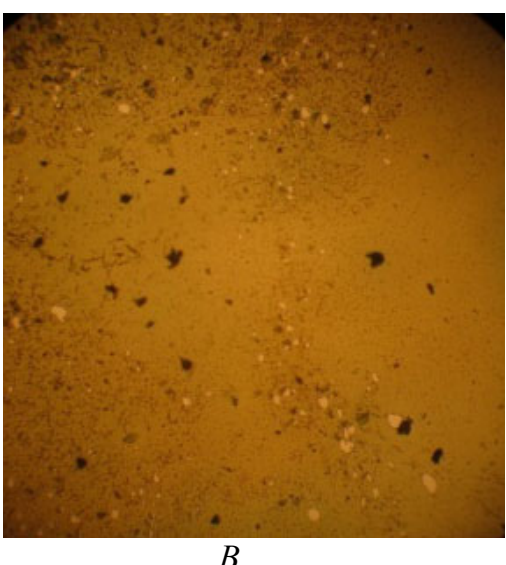

$B$

Fig. 3. Microphotos of the PoTi $(a)$ and PoA $(b)$ films electrodeposited on the $\mathrm{SnO}_{2}$ surface

The relative change in optical absorption $(\Delta \mathrm{D})$ at a certain wavelength $(\lambda, \mathrm{nm})$ referred to the initial value of A in the absence of gas, was chosen to evaluate the sensitivity of the films to various gases presented in the Table. The maximum of sensitivity to the organic vapors for PoTI films in all cases is observed at $\lambda>550 \mathrm{~nm}$ and extends to near-infra-red area indicating a formation of free charge carriers of polaron type (Bai et al., 2007; Khan et al., 2015). Nonpolar solvent vapors insignificantly affect the optical properties of polyaminoarene films (table 1).

Therefore, it is established that the maximum sensitivity of PoTi to vapors of organic solvents at $550 \mathrm{~nm}$ increases in a number of chloroforms, DMF, THF. The maximum optical response to the adsorption of unipolar aromatic solvents, such as toluene and nitrobenzene, is observed at a shorter wavelength, namely at $400 \mathrm{~nm}$.

An important indicator of the success of the sensor element is its response speed. For the PoTI films the time of

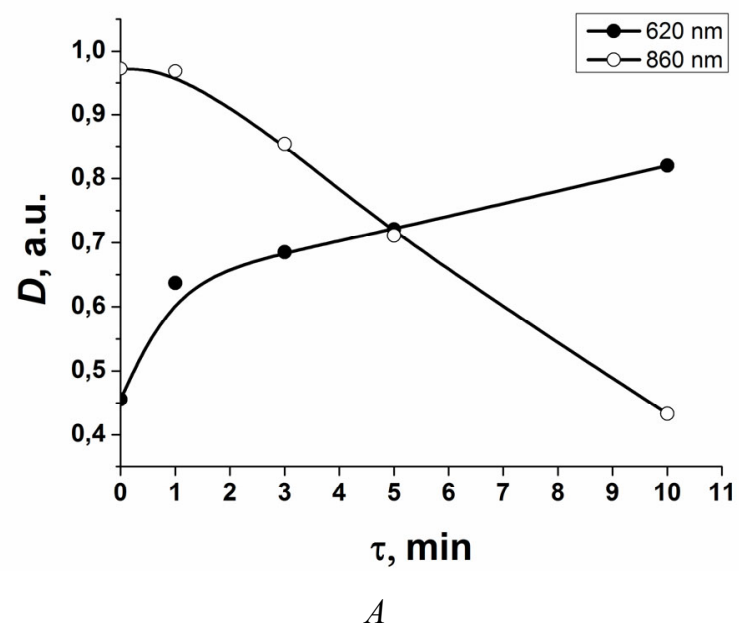

response on DMF and chloroform action is near $60 \mathrm{~s}$ (fig. 3) at both wavelength $550 \mathrm{~nm}$ and $810(850) \mathrm{nm}$.

Table 1

Sensitivity of PoTI films to organic solvent vapors

\begin{tabular}{cccc}
\hline \multirow{2}{*}{ Solvent } & \multicolumn{3}{c}{$\Delta \mathrm{D} / \mathrm{D}, \%$} \\
\cline { 2 - 4 } & $400 \mathrm{~nm}$ & $550 \mathrm{~nm}$ & $800 \mathrm{~nm}$ \\
\hline Chloroform & 7,4 & 32,6 & 25,7 \\
DMF & 1,1 & 35,2 & 10,3 \\
THF & 9,7 & 54,2 & 9,3 \\
Nitrobenzene & 22,5 & 19,6 & 15,8 \\
Toluene & 21,4 & 11,7 & 20,1 \\
\hline
\end{tabular}

As can be seen from fig. 4, the stationary value of the PoA optical response on the DMF action is reached within 120-180 s only for $\lambda=620 \mathrm{~nm}$. At the $\lambda=860 \mathrm{~nm}$ a decrease in optical density is observed during $10 \mathrm{~min}$ and more. In the case of THF vapors action on PoA film a stationary value of $\mathrm{D}$ achieves more quickly in the time $60-90 \mathrm{~s}$.

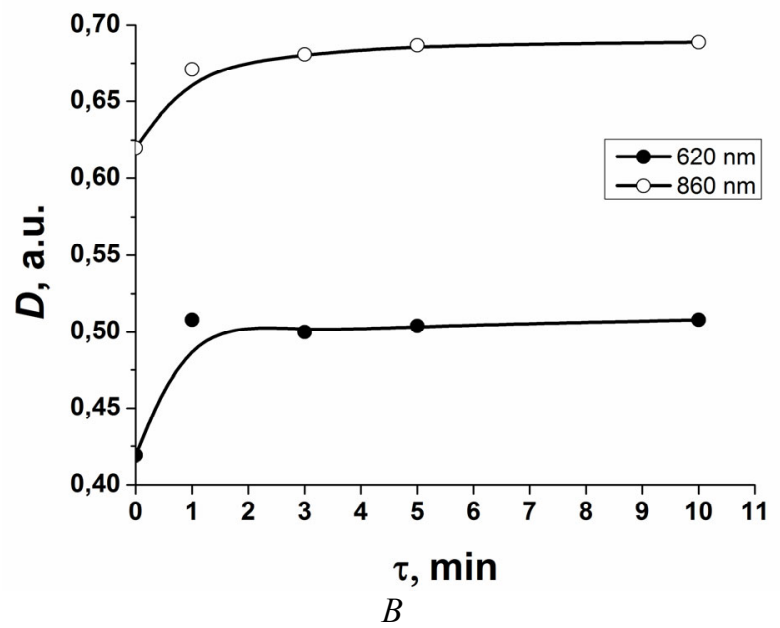

Fig. 4. Temporal dependence of the optical density of PoA film in the action of $(a)$ DMF and $(b)$ THF vapors;

$$
P=7,2 \mathrm{kPa}
$$




\section{Table 2}

Sensitivity of PoA films to organic solvent vapors at different wavelength

\begin{tabular}{ccc}
\hline \multirow{2}{*}{ Solvent } & \multicolumn{2}{c}{$\Delta \mathrm{D} / \mathrm{D}, \%$} \\
\cline { 2 - 3 } & $620 \mathrm{~nm}$ & $860 \mathrm{~nm}$ \\
\hline Dimethylformamide & 58,1 & 26,9 \\
Tetrahydrofuran & 20,3 & 10,8 \\
\hline
\end{tabular}

Different character in the changes of optical absorption in PoTI and PoA films found for organic solvents vapors may be useful for selective detection of polar and nonpolar solvents in technological processes.

\section{Conclusions}

Based on the spectral dependence of the optical absorption of polyortotoluidine and polyorthoanisidine films, the presence of the main bands in the region of $400-450,550-570$ and $650-900 \mathrm{~nm}$ due to electronic transitions in the conjugated polyaminoarene system and the presence of polaron and bipolaron type carriers has been established.

The spectral sensitivity of polymer films to the action of organic solvents (dimethylformamide, tetrahydrofuran, chloroform, etc.) has been established. The proposed approaches to the creation of sensors for detecting vapors of organic solvents can be the basis for the development of new selective and fast-acting devices for monitoring gaseous media in the chemical, medical and cosmetic industries.

This work was supported by the project of Ministry of Education and Science of Ukraine "Development of composite organo-inorganic heterostructures for reversible gas sensors" (state registration number 012990U101998).

\section{Prospects for further research.}

For the first time, the sensitivity of thin films of polytoluidine and polyanisidine to the action of vapors of organic solvents was established. This sensitivity provides prospects for the development of optical gas sensors to detect harmful fumes of organic substances used in various industries and medicine. Based on the obtained results, models of optical sensors for monitoring gaseous media in production facilities with high selectivity will be proposed. The next step is to study the reversibility of sensor films to the action of organic vapors and optimization of the sensor design.

В роботі вперше встановлена чутливість тонких плівок політолуїдину і поліанізидину до дії парів органічних розчинників. Така чутливість дає перспективу для розробки оптичних газових сенсорів для виявлення шкідливих випарів органічних речовин, які використовуються в різних галузях промисловості i медицини. На основі отриманих рузультатів будуть запропоновані макети оптичних датчиків моніторингу газових середовищ у виробничих приміщеннях, які володітимуть високою селективністю. Наступним кроком буде вивчення реверсивності сенсорних плівок до дії органічних випарів та оптимізація конструкції датчиків.

\section{References}

Aksimentieva, O., Tsizh, B., \& Chokhan, M. (2018). Sensors of control of gaseous media in the food industry and the environment. Pyramida, Lviv. ISBN 978-966-441-509-2.

Aksimentyeva, O. I., Tsizh, B. R., Horbenko, Yu. Yu., Konopelnyk, O. I., Martynyuk, G. V., \& Chokhan', M. I. (2019). Flexible elements of gas sensors based on conjugated polyaminoarenes. Mol. Cryst. Liq. Cryst, 670(1), 3-10. doi: 10.1080/15421406.2018.1542057.

Bai, H., \& Shi, G. (2007). Gas sensors based on conducting polymers. Sensors, 7, 267-307. doi: 10.3390/s7030267.

Dong, X., Zhang, X., Wu, X., Cui, H., \& Chen, D. (2016). Investigation of gas-sensing property of acid-deposited polyaniline thin-film sensors for detecting $\mathrm{H}_{2} \mathrm{~S}$ and $\mathrm{SO}_{2}$. Sensors, 16, 1888-2003. doi: 10.3390/s16111889.

Horbenko, Yu., \& Aksimentyeva, O. (2013) Structure and physical-chemical properties of poly-ortho-anisidine doped with ferric (III) chloride Visnyk LNU. Ser. Chem, 54(2), 353-357. URL: http://publications.Inu.edu.ua/ bulletins/index.php/chemisrty/article/view/6646/6644 (in Ukrainian).

Hu, C.-W., Yamada, Y., \& Yoshimura, K. (2017). A new type of gasochromic material: conducting polymers with catalytic nanoparticles. Chem. Commun., 53, 3242-3245. doi: 10.1039/C7CC00077D.

Khan, A. A., \& Shaheen, S. (2015). Electrical conductivity, isothermal stability and amine sensing studies of a synthetic poly-o-toluidine/multiwalled carbon nanotube/Sn(IV) tungstate composite ion exchanger doped with p-toluenesulfonic acid. Anal. Methods, 7, 20772086. doi: 10.1039/C4AY02911A.

Savale, P. A., Shirale, D. J., Datta, K., Ghosh, P., \& Shirsat, M. D. (2007). Synthesis and characterization of poly (oanisidine) films under galvanostatic conditions by using ECP technique. Int. J. Electrochem. Sci., 2, 595-606. URL: http://www.electrochemsci.org/papers/vol2/ 2080595.pdf.

Tsizh, B., \& Aksimentyeva, O. (2020). Ways to improve the parameters of optical gas sensors of ammonia based on polyaniline. Sens. Actuator A Phys, 315, 112273. doi: 10.1016/j.sna.2020.112273.

Tsizh, B. R., Dzeryn, M. R., \& Horbenko, Yu. Yu. (2017). Gas sensitivity of poly-ortho-toluidine films. Scientific Messenger LNUVMBT named after S.Z. Gzhytskyj, 19(75), 59-64. URL: https://nvlvet.com.ua/ index.php/food/article/download/3095/3122/ (in Ukrainian). 